\title{
NGESTI UTOMO RODHAT DANCE AS A MEANS OF BERSIH SENDANG DADAPAN RITUAL IN BOYOLALI REGENCY
}

\author{
Suharji \\ Indonesia Institute of Arts, Surakarta, \\ $凶$ Jl. Ki Hajar Dewantara 19 Surakarta 57126, Indonesia \\ E-mail: suharji_harji@yahoo.com
}

Received: October 22, 2014. Revised: November 1, 2014. Accepted: November 24, 2014

\begin{abstract}
Rodhat dance is one of the dances used for Bersih Sendang ritual in the slope of Mount Merbabu. This study investigated the role of Rodhat dance in Bersih Sendang ceremony. This study was conducted using qualitative method, and the data collection techniques were observation, interview, and documentation. The approach used in this study was anthropological approach. Data analysis techniques in this study were reduced, reformation, and conclusion. The result of this study shows that Rodhat dance is a folk dance used as a means of ritual in the society. The accompaniments of the ritual are sesaji (offerings) and ujuban (prayer). Acculturation occurred due to the mix of the ancestor's worship tradition and Islamic tradition. The dance is conducted every year to free the spring from bad attitudes of human beings, so that the water in the spring is always available for the welfare of the local society. With the plentiful water, the people is happy because their farm is irrigated. Bersih sendang ritual is an expression of gratitude to The Creator who has given His gift to the people living in Gunungan Lor, Jeruk village, Sela sub-district, Boyolali regency.
\end{abstract}

Keywords: acculturation; bersih sendang; ritual; rodhat dance

How to Cite: Suharji. (2014). Ngesti Utomo Rodhat Dance as a Means of Bersih Sendang Dadapan Ritual in Boyolali Regency. Harmonia: Journal of Arts Research and Education, 14(2), 140-146. doi:http://dx.doi.org/10.15294/harmonia. v14i2.3295

\section{INTRODUCTION}

Bersih Sendang ritual is part of the cultural aspect which has become a tradition, and it is preserved by some people living in Gunungan Lor, Jeruk village, Sela sub-district, Boyolali regency in order to get the blessings in the form of sufficient water supply needed by every human. Bersih Sendang ritual can still be found in some areas in Central Java, such as Undaan in Kudus, and Jimbung in Southern Klaten. This tradition is the social manifestation of the power of nature. There are various ways in conducting this tradition, such as tirakat, sedekah bumi and folk art performance. The attitudes of rural society are usually adapted to the natural condition in order to maintain the harmony with the nature. Many rules and prohibition are made for that purpose. For example, sesaji (offerings) should not be something fried or crispy or dried because it is contrary to water, something wanted by the people. It is not allowed to burn incense in a mosque, but almost all people smoke cigarettes with incense so that the smell is everywhere in the mosque. It is believed that if someone does something prohibited, his village will be in danger. It will be difficult to find water so that people will have a serious problem. Big trees around the spring must 
not be cut, and they are considered sacred because of supernatural beings dwelling those trees. If those trees are cut, disasters such as land-slide or drought will occur. There is no logical reason for those traditions since people just follow what is told by the elders. Bersih Sendang Dadapan ritual which is conducted every Bakdamulud (a Javanese month) on Rebo Pon (Rebo, Wednesday; Pon, a name of a day in Javanese calendar) is always accompanied by Rodhat dance from "Ngesti Utomo" art association led by Tarji and Nursalim. This art festival is held on the day from 15.00 until 17.00 and at night from 20.00 until 23.00. This event involves three types of traditional Rodhat dance, which are performed by women, by men, and by both women and men. The performers are chosen from the people living in the area of RT $01 \mathrm{RW}$ OI. This study explains how Bersih Sendang ritual is conducted in Gunungan Lor and how Rodhat dance is. Theoretically, this study gives clearer information about the ritual with Rodhat dance, which is influenced by Islamic values.

\section{The Form of Dance as a Means of Ritual}

According to Soedarsono, the characteristics of ritual are a proper selection of day, dancers who are accustomed to the ritual, a specific place, sesaji or offerings, and prayers (Soedarsono, 1999, p. 162-163).

In the abstract sense the definition of art form is a structure. The structure in the dance is a set of relationships in unity. It refers to the relationships among parts of a whole unit. In the concrete sense, form means an arrangement. Then, the concept of form is related to parts of a whole. In the context of Rodhat performance as a means of ritual, the study of the form examines parts of the dance performance as an aesthetic activity for human beings who desire beauty. The form of art must be so interesting that its audience can enjoy it. A performance needs audience's appreciation, and therefore a dance performance as a set of movement, stage design, make-up, costumes and music is arranged beautifully to satisfy its audience.

\section{METHOD}

\section{Research Methods and Approach}

This study was a qualitative study resulting in descriptive data in the form of written or spoken elaboration or the explanation of a policy (Moleong, 2002, p. 112). This study applied anthropological approach which considers art as an expression of human feelings. However, Rodhat dance has its social aspect due to its missionary purpose. The data were collected directly from the sources, and the researcher became part of the main analytical instrument. The data were in the form of words or pictures with certain meanings (Sutopo, 2006, p. 40). The main data sources were verbal expressions and actions, and the additional sources were pictures and recordings of Karawitan (Javanese music ensemble.

\section{Data Collection Techniques}

The data collection techniques were observation, interview, and documentation. The observation was conducted in two ways, namely direct observation of the sources and indirect observation through recordings made in this study. In the direct observation, the researcher observed the preparation of sesaji and kenduri (an expression of gratitude to God by gathering people, praying together, and giving them food) by actively participated as a participant in Masjid Jami' Gunungan Lor where Rodhat dance was performed. Those processes were also recorded so that there was no missing information. The indirect observation was conducted by observing the recordings made in the direct observation and the ones made before it from library collections, in addition to books. The use of computer helped the image transfer process. Besides, the researcher examined the data kept by the leaders of Ngesti Utomo.

The interview was conducted in two ways, namely free interview and programmed interview. Free interview was conducted to some informants in order to obtain general data. This interview had been conducted since the researcher came to the 
field. The questions of the interview included the history of Rodhat dance, the history of the artists, the artistic concept, and the artists' artistic expressions. Free interview was intended to get along well with the informants and make them open to share required information for the purpose of the study. The interview was noted and videotaped, so that there was no missing information. The main informants were Nursalim, 43 years, living in Gunungan Lor and acted as the co-leader of Rodhat accusation, and Tarji, 40 years, living in $\mathrm{Du}$ sun Gunungan Lor and acted as the head of the committee of bersih sendang. From the interview, the researcher obtained the data related to the month in which bersih sendang was conducted, the process, and the required money. The other informants were Dulkamit, 58 years, from Gunungan Lor. They gave the data about the prayers and sesaji. Other important information about the development of Rodhat dance and the condition of the local society was obtained from one of the pioneers of traditional Rodhat dance, Jarkoni, 64 years.

Programmed interview was conducted to obtain necessary data for the study. The researcher had prepared a list of questions related to the conduct of the ceremony, selamatan (or kenduri), funding, dramatic structure of Rodhat dance, the history of the performers, institution conducting the event, supporting factors, obstructions, the ways of overcoming problems, and the number of audience. The main informant was the leader who was also a dance trainer named Ki Warsito, 39 years, a farmer. Ki Warsito is the creator of Tari Prajuritan Gagrak Tumapel which made him a well-known artist in Boyolali regency. He actively participated as a trainer of Rodhat "Ngesti Utomo" and Rodhat Kalijaga from Suboto village. He provided the data about the performers of Rodhat dance, the participation in the ritual, and the spirit to preserve the dance.

The form of the performance, the equipment, and the environment in the supporting society were documented using audiovisual means. This study at- tempted to find the relation of Rodhat performance with the belief of the society and the artists with the cultural life of their supporting society.

\section{Data Validation Technique}

The data of this study is validated through data triangulation technique. According to Moleong (2007, p. 178) triangulation is a data validation technique which uses something outside the data themselves in order to check or compare the data. Triangulation techniques applied in this study were triangulation of data source and triangulation of methods.Triangulation of data source is a technique to explore some different data sources in order to obtain similar data as a way of validating the data. Triangulation of methods is data collected from similar sources using different techniques.

\section{Data Analysis Technique}

The data of this study were analyzed using interactive process. The data collected from interviews were compared to data from observation. Next, the data were analyzed using three analysis components, namely data reduction, data presentation reformation, and conclusion or verification. Data reduction was conducted by analyzing the data related to the ritual, the form of Rodhat performance, supporting factors and obstructions, and functions, which were selected, simplified, and abstracted. Data reformation was a complete arrangement of information and description. The conclusion was made when there were sufficient data. When there was missing information, the researcher came back to the dancers, committee and members of of Ngesti Utomo to obtain the required data.

\section{RESULT AND DISCUSSION}

\section{Geographical Condition of Gunungan Lor}

Dusun Gunungan Lor is one of fifteen Dusun (small village) in the area of Jeruk in the eastern slope of Mount Merbabu. Gunungan Lor is confined in that slope, with 
Dusun Surodadi in the western side of the area, Dusun Tempel of Suboto village which is part of the Semarang regency in the north, a downward-sloping road in the east, and farmland in the south. In order to reach the area, someone can ride a motorcycle or drive a C-class car. Big vehicles can only reach Dusun Surodadi due to its narrow road. The road to Gunungan Lor has been covered with asphalt with 50 -degree declivity. This area has narrow roads. The houses in this small village are clean, and the architecture is the typical style of village house characterized by the narrow front yard, unplastered walls, and tiled floor. Almost all houses have walls made of bricks from soil, bricks from cement, and stones. There is limited water, so that some people depend on rain as a source of water and distribute the water to several houses. Water is a crucial thing in this village, so the ritual of searching for sources of water is conducted. Dadapan spring is one of the important sources for people living in $\mathrm{Du}$ sun Gunungan Lor.

\section{Kinship}

The relationships between an individual and another one, among a group of individuals, and with the nature encourage human beings to know each other, fulfill biological, physical, and mental needs. Human beings then create various tools and technology, arts, and patterns of attitude known as culture. In culture, there are patterns of kinship. Based on the observation, the people in Gunungan Lor and the members of Ngesti Utomo were very close to each other without disparities, and they lived with a traditional system called paguyuban (togetherness and close interaction with a group people). All people participated in every activity, and the money for the ritual was from donations. The dance performance also involved almost all people living in RT 01, RW 01 Gunungan Lor (Ki Tarji, interview on February 13, 2012). Dusun Gunungan Lor consists of one Rukun Tetangga or RT (a small area in a village with a few people living close to each other) in one Rukun Warga or RW (a small area in a village which is larger than RT) with 49 houses in which 251 people lived.

\section{The Tradition and the Ritual of Bersih Send- ang Dadapan}

Almost all people still embrace the tradition from the ancestor, and this can be seen when the elder people burn incense and cast a spell in the ritual. Ujub is an acculturation of the expression of gratitude to the prophet and dahyang (supernatural being dwelling certain places), while the prayers are all taken from Al Qur'an. Almost all people gather around sausage accompanied by the prayers of the elders. There are three types of sesaji in the ritual. the first offering, which is given in the morning, consists of bunga telon (three kinds of flower) and boreh, big tumpeng (cone-shaped rice), ingkung ayam (chicken), crackers, a bunch of banana, traditional snack or jajan pasar, and dawet and so on. Ujub sesaji is intended to be delivered to the prophet Muhammad SAW, supernatural beings in bale griyo inside and outside wangon, Baginda Kilir the ruler of water and Baginda Ilyas the ruler of the land. This is conducted every Jumadil akiran of Jumat Kliwon. It is expected that they give their blessings for safety, peace, and success of the people living in Gunungan Lor.

Prayer for safety in Bersih Sendang is conducted after ujub sesaji, which is symbolized by burning incense and casting a spell. This is done for safety, prevention from danger, plentiful water in Dadapan spring, and a good crop of vegetables and palawija (supplementary food other than rice). Before the time of dhuhur (midday prayer), all people gather in the mosque of the village for selamatan (Javanese grateful ceremony). All people bring tumpeng, steamed tahu and tempe, vegetables, and a lodong dawet. No fried food is allowed. There is no incense which is burned, but almost everyone smokes cigarette with incense or klembak menyan, so that the smell is everywhere. One of the elder people, then recites prayers, and the participants replied the prayers by saying amen. After 
that, everyone can eat the food brought by them.

The offerings consist of a cup of sweet tea, two cigarettes, baked sweet potato, baked cassava. The prayer is recited by the leader of Rodhat group. All prayers in kenduri are influenced by Islam. The first prayer is Alfatihah verse, then the prayer for both parents, the prayer for the fellow Moslems, and the prayer for safety in the world and the afterlife.

After selamatan, there is an art festival in which people perform folk dances. Folk dances are usually simple with no detailed work on movements, and they function more as entertainment and tribute to the supernatural beings for certain purposes. Ritual dances are performed for overcoming any disruptions, either naturally or supernaturally. Ritual dances are always related to supernatural things.

\section{Ngesti Utomo Rodhat Dance}

Ritual ceremony is something rare since it is used by a certain society only in a certain occasion. Ngesti Utomo Rodhat dance is performed specifically to accompany Bersih Sendang ritual which has been held for a long time ago. Rodhat dance is performed to commemorate ki Ario Saloka and Munding Sari from Mount Merbabu for their merit to the people of Gunungan Lor. Since 2010, there are three traditional Rodhat groups, each of which is performed by men, women, and both men and women. Most people living in Gunungan Lor believe that the dance has magical power. Female Rodhat dance is performed at the beginning of verse sendang, followed by male Rodhat dance, and then all dancers dance together as the closing. The performance is intended to get angsar or benefits. The performance is held in a wide open space with tepak panggung made of sengon wood owned by a local dance group for the accompaniment.

\section{Dance Forms}

The form of Rodhat dance to complete the rites is Prajuritan dance with an Islamic theme,a religion of most Gunungan Lor- people (Jarkoni, interviewed on February 13, 2013). The forms of Rodhat dance include the sequence of staging, make-up and fashion, and Karawitan music supporting the dance.

\section{Sequences of Staging}

Before the dance begins, there is terbangan (Islamic percussion ensemble) accompanied with the synopsis of the origin of the dance, which is said to be an expression of gratitude to the warriors of Mount Merbabu called Aryo Saloka and Mundingsari. The dance consists of several movements. First, the dancers walk in a row consisting of four persons and energetically wave the fans in their right hands vertically, while their left hands wave in the similar direction to the fans. All the dancers enter the stage in five rows, each of which consists of four dancers. Second, after the accompanying music changes into Gendhing (Composition of Javanese orchestra) with rearranged composition, the dancers dance with clenched left and right hands, slightly bent bodies, and heads turning left and right. Left and right hands are moved vertically, and bodies are moved upright and bent alternately and turned left and right. Left and right feet are moving and bodies are bent. The dancers then take the position in which their heads are turned left and right while they move their heads left and right alternately. Third, the music changes into Gamelan from saron penerus and drum. The dancers form a 4-5 formation, forming a crossed pattern and then two columns. Fourth, the music changes into terbangan, the dancers walk and wave their fans, forming a circle and facing each other. Fifth, the music changes into compositional music, the dancers perform $J a-$ lan Kicat, wave their fans and face each other then turn around back to back. Every movement change, the dancers wave their fans and perform Jalan Kicat. The dancers start with a circle formation facing each other, with left hand akimbo and right hand holding fans in front of the stomach, and then they walk sideways to the right and make a circle. The dancers then form 
information while slightly bending their bodies and then make a circle again. Sixth, the music changes into ganjur, two couples in the north and the southern sides face each other and then face other dancers in the west and the east. Seventh, composing music is played, the dancers form a faceto-face formation with four dancers facing four others and then form a two column formation. Eight, the music changes into srepeg, the dancers form a circle while waving their fans, face each other and then turn around back to back. The ninth, the music gets more intense, and the dancers perform acrobatic movements. Tenth, the music reaches its peak, the dancers form an acrobatic formation like a mountain, and then make a two column and leave the stage.

Energetic dance as an expression of the feeling of the society has a great power and benefits for them (Ki Warsito, interview on May 10, 2012). The letter formations represent the name of the association. What is important in the ritual dance is the spirit of togetherness and harmony for reaching inner peace rather than its aesthetic aspects.

\section{Make-up and Costumes}

Make-up is used to make a change to the dancers' faces. The colors used are mostly black and white. Face powder is applied first, and then the eyebrows and sideburns are bonded using black pencil. Thus, the men look handsome and the women look beautiful.

The costume consists of black cap called peci with yellow edge, sunglasses, white long-sleeve shirt for men and women, golden cloth slings, black or green vest, bangles, black cinde pants, and sandals.

\section{Karawitan as the Accompaniment}

Karawitan used in Rodhat dance is a combination of Javanese Karawitan and terbangan. The instruments are four terbang (a kind of percussion), three saron penerus, one bedhuk, one drum and one organ (see Figure 2). There is acculturation in this accompaniment. Diatonic music is mixed with pentatonic one. This new creation of music supports the performance very well.

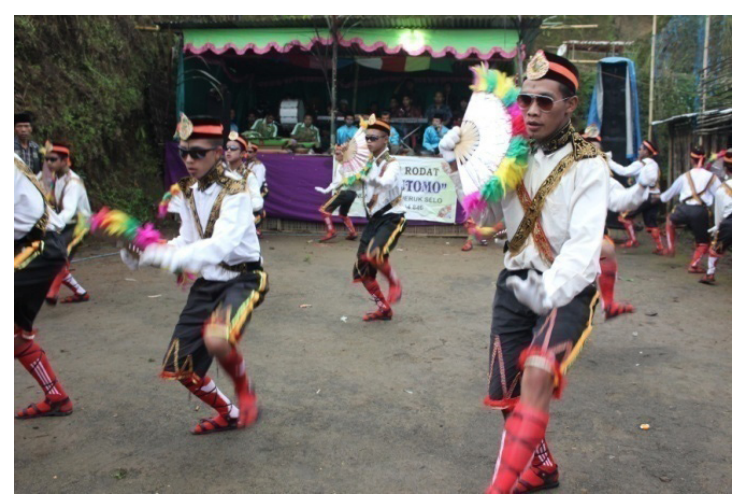

Figure 1. Costumes for Male Dancers

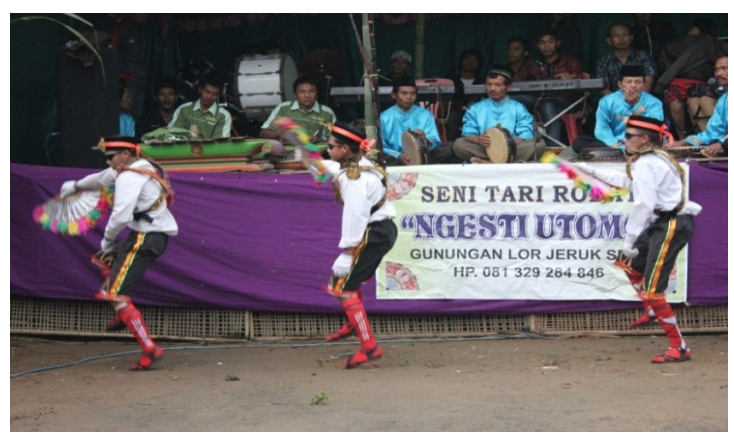

Figure 2. Instruments used in Rodhat performance

\section{CONCLUSION}

Bersih Sendang ritual in Gunungan Lor, which was previously a means of spreading Islam and an entertainment, developed into a means of praying for water as a source of fertility needed by the people there. Drought causes crop failure and makes the people suffer. Therefore, it is necessary to cooperate and work together to undergo and overcome it. It is believed that preserving Rodhat performance gives them fertility for their land, safety, peace, and happiness.

The form of Rodhat performance in Bersih Sendang ritual comprises the sequence of the performance, make-up and costumes, and Karawitan as the accompaniment. 


\section{REFERENCES}

Abdullah, M. I. N., Bakar, S. A., \& Annuar, T. M. (2013). Rodat: Budaya Tradisi yang Berevolusi. Wacana Seni Journal of Arts Discourse, 12(2), 25-34.

Ambarwangi, S. (2014). Reog as Means of Students' Appreciation and Creation in Arts Culture Based on the Local Wisdom. Harmonia Journal of Arts Research and Education, 14(1), 37-45.

Ananda. (2011). Ebleg Akar Kesenian Kuda Lumping. Retrieved http://adisulistyo.wordpress. com/2011/05/06/ ebleg-akar-kesenian-kuda-lumpingebleg-the-root-of-traditional-kudalumping-dancing. May 16, 2014.

Ariani, C. (2003). Seni Pertunjukan Tradisional. Yogyakarta: Kementrian Kebudayaan dan Pariwisata.

Arnold, H. (1979). The Sociology of Art Trans Kenneth J. Northcott. Chicago: The University of Chicago Press.

Atkinson, P., \& Amanda, C. C. S. (2001). Handbook of Ethnography. London: SAGE Publications Ltd.

Had, S. (2005). Sosiologi Tari: Sebuah Pengenalan Awal. Yogyakarta: Pustaka,

Had, S. (2007). Kajian Tari teks dan konteks. Yogyakarta: Pustaka Book Publiser.

Harjadi, D. (2013). Bentuk dan Fungsi Kesenian Rodat pada Upacara Ritual Potong Gembel di Desa Dieng Kulon Kecamatan Batur Banjarnegara. Thesis. Semarang: Universitas Negeri Semarang.

Holt, C. (2000). Melacak Jejak Perkembangan Seni Pertunjukan di Indonesia. Translated by R. M. Soedarsono. Bandung: MSPI.

Iswandi. (2012). Perkembangan Kesenian Kuda Kepang di SAwahlunto Minangkabau. Ekspresi Seni, 14(2), 112-123.
Jazuli, M. (2011). Mandala Pendidikan Seni. Harmonia: Journal of Arts Research and Education, 6(3), 202-211.

Jazuli, M. (2012). Sosiologi Seni. Surakarta: UNS Press.

Maleong, L. J. (2007). Metode Penelitian Kualitatif. Bandung: PT Remaja Rosdakarya.

Merriam, A. P. (1964). The Antropology of Music. Bloomington: Northwestern University Press.

Muhadir, H. N. (2000). Metodologi Penelitian Kualitatif (fourth edition). Yogyakarta: Rake Sarisin.

Murdowo, S. (2006). Objektivitas Imajinasi dalam Seni. Harmonia Journal of Arts Research and Education, 4(1), 22-31.

Ratna, N. K. (2010). Metode Penelitian Kajian Budaya dan Ilmu Sosial Humaniora Pada Umumnya. Yogyakarta: Pustaka Pelajar.

Soedarsono, R. M. (1998). Seni Pertunjukan Indonesia di Era Globalisasi. Jakarta: Direktorat Jenderal Pendidikan Tinggi Departemen Pendidikan dan Kebudayaan

Soedarsono. (1999). Seni Pertunjukan dan Pariwisata Rangkuman Esai tentang Seni Pertunjukan Indonesia dan Pariwisata. Yogyakarta: BP ISI.

Soekanto, S. (1987). Sosiologi suatu Pengantar. Jakarta: Rajawali Press.

Soewondo. (1975). Pembinaan dan Pengembangan Tari Tradisional. Jakarta: Pustaka Jaya.

Subandi. (2011). Upacara Bersih Dusun Ngagrong Atas, Desa Ngagrong Ampel Boyolali. Gelar, 9(1), 88-99.

Suharji. (2011). Tayub Janggrungan Sebagai Sarana Upacara Lempokan Nyiwer Sawah. Panggung Jurnal Seni dan Budaya, 21(2), 130-139.

Sutopo, H. B. (2006). Metode Penelitian Kualitatif. Surakarta: UNS Press. 